\title{
Financial Power and Democratic Legitimacy: How To Think Realistically About Public Debt
}

\author{
Janosch Prinz (Maastricht University) and Enzo Rossi \\ (University of Amsterdam) \\ Penultimate version, unconditionally accepted for publication \\ in Social Theory and Practice (2022)
}

\begin{abstract}
To what extent are questions of sovereign debt a matter for political rather than scientific or moral adjudication? We answer that question by defending three claims. We argue that (i) moral and technocratic takes on sovereign debt tend to be ideological in a pejorative sense of the term, and that therefore (ii) sovereign debt should be politicised all the way down. We then show that this sort of politicisation need not boil down to the crude Realpolitik of debtor-creditor power relations-a conclusion that would leave no room for normative theory, among other problems. Rather, we argue that (iii) in a democratic context, a realist approach to politics centred on what Bernard Williams calls 'The Basic Legitimation Demand' affords a deliberative approach to the normative evaluation of public debt policy options.
\end{abstract}

Key words: Sovereign debt; public debt; ideology; political realism; Greek crisis.

\section{Introduction}

In this paper we put forward an argument for politicising public debt in ways compatible with the requirements of democratic politics. Sovereign (or public) debt ${ }^{1}$ is currently at the forefront of politics in Western states. ${ }^{2}$ Policy initiatives are often met with the question "How are you going to pay for it?" before the

\footnotetext{
${ }^{1}$ Sovereign debt is broadly the sum of accrued government spending not offset by taxation. Implicit debt would include interest payments on outstanding government bonds. We are considering public debt owed to other states and to private market actors, but not debt that is owed to the other branches of the state.

${ }^{2}$ By using 'sovereign debt' and 'public debt' interchangeably we restrict the domain of our argument to polities characterised by a democratic ideal of popular sovereignty.
} 
content of the initiative is even considered. What is politically possible is limited by what is deemed financially stable. Determining what is financially stable is widely viewed as a technical question best answered by economics. Failures of financial stability tend to be framed in a moralising tone along the lines of: "We will have to bail them out for their profligacy and their laziness!", or by reference to seemingly incontrovertible scientific truths such as simple accounting equivalences: "Look at the national debt! We can't spend more than we have coming in!" In this paper we argue that both of those approaches are ideological in a pejorative sense of the term, and so won't do, especially in a context in which democracy purportedly matters.

Moralising and technocratic narratives about profligate states and the economic limits to deficits and public debt have been a mainstay of European public discourse since the Great Financial Crisis (GFC) has been addressed as a sovereign debt crisis (for arguments that this way of addressing the overall crisis is already a political choice, see Frieden and Walter 2017; Tooze 2018). In moralising narratives, states appear either as people who do not keep promises and are hence morally debased, or as households which live beyond their means. In technocratic narratives, states are urged to heed advice about sustainable levels of budget deficits and debt-to-GDP ratio. In the Economic and Monetary Union (EMU), the technocratic narratives about deficits and debt are enshrined in European treaties, now mostly tied together in The Fiscal Compact (Roos 2019: 301). These narratives tend to claim to be above the political fray: they aim to displace politics with technical administration or with the application of moral principles. We will argue that neither narrative is tenable, for a range of reasons. Politics cannot be eliminated from questions of public debt without misrepresenting the issues at stake-that is to say, without ideological distortions.

Our alternative proposal is that, to counter the danger of ideology, public debt must be politicised all the way down (and that is to say, as we will seem down to the level of all those affected by the politics of public debt). One may take that to mean that debt is just a matter of Realpolitik: crudely speaking, creditors and debtors backed up by force weighing the opportunity cost of default, enforcement, and so on. That picture would leave little room for a normative theory of sovereign debt. We reject the false choice between depoliticization (moralism and technocracy) and the Realpolitik of public debt. Instead, we argue that a realistic understanding of politics can keep that theoretical space open, without lapsing into either technocracy, or moralism, or both. We aim to show 
that a critique of the ideology of public debt affords an opportunity for a genuinely democratic politicisation of debt relations, thanks to re-elaboration of Bernard Williams' realist theory of legitimacy. We argue that, in a context in which democracy purportedly matters, the politics of public debt require a form of non-ideological (in the pejorative sense of the term), non-moralised justifiability of the relevant power relations. We show how a realistic, power-centric-as opposed to moral status-centric-conception of democracy can ground a requirement for the public justifiability of public debt-related political decisions. We then make some practical suggestions about how this justifiability may be achieved.

Attention to sovereign debt has been sparse in political theory ${ }^{3}$ until a recent spike in interest in the topic which has been focused primarily on the ethics of sovereign default during debt crises (Wiedenbrüg 2017; 2018; Wollner 2018). ${ }^{4}$ These writings take on the important task of challenging the idea that sovereign debts have to be paid in full no matter what ("pacta sunt servanda" etc.). However, whether they start from the odious debt literature or from procedural questions of democratic legitimacy in the context of financial markets, they tend to remain anchored to the technical-economic and moralizing approaches (e.g. by framing the question as one of when the "repayment norm" holds). The normative scrutiny of central banks since the Great Financial Crisis has questioned the legitimations offered for their expanded powers and demonstrated the need to rethink the basis for the legitimacy of independent central banks (Klooster 2018; 2020a; 2020b; Klooster and Fontan 2019; Best 2016, 2018). The suggestions for remedies have included a shift from purely technical rules and procedures for transparency and accountability to questions of political legitimacy of (the scope of) their mandates (Klooster 2020a; Best 2016, 228). However, the most systematic accounts have been shaped by a view of political philosophy as applied ethics, and so focused on developing a moral framework for improving justification of mandates and intra-institutional deliberation. ${ }^{5}$ Political economists (Roos

\footnotetext{
${ }^{3}$ As debt used to be a major theme in the history of political thought, its absence in the second half of the twentieth century is surprising. We view this as a symptom of the scant attention to power in Anglophone analytical political philosophy during this period (Thanks to Eric Schliesser for highlighting this observation). More attention has been paid to the normative consequences of sovereign indebtedness in terms of the self-determination of states in the Global South.

${ }^{4}$ Alexander Douglas's timely The Philosophy of Debt (2016) provides a more general philosophical treatment of the institution of debt which also reaches into macroeconomics and public finance.

${ }^{5}$ Klooster 2020a, 589-591; for a defense of unelected monetary power,
} 
2019) and historians (Dyson 2014; Stasavage 2003) have debated sovereign debt in much more detail, though those disciplines mostly refrain from engaging with normative issues. We will take a realist approach in order to place those empirical findings in the service of a normative political theory that does not fall back onto moral commitments (mis)construed as prepolitical.

A striking recent example of the direct and dramatic ways in which the discourse about, and governance of, sovereign debt displace politics is the agreement of the third rescue package between Greece and the ECB, IMF and European Union (the "Troika") - a 2015 case whose political echo is all too audible, for example, in the 2020 negotiations about the financing of the European Union's Coronavirus response (Varoufakis 2020). In 2015 the left-wing Syriza government agreed to the austerityinducing rescue package despite the fact that a very recent referendum, which they had initiated, rejected the terms of the agreement. In the next section, we analyse the Greek crisis to substantiate our contention that both technocratic and moralistic takes on public debt aren't what they seem: they misrepresent the interests at stake as well as the available options, and so are ideological in a pejorative sense of the term. ${ }^{6}$ In the subsequent section we articulate what we take that diagnosis to entail, namely that public debt should be politicised all the way down. That will allow us to return to our initial case study and show how, in a way, what went wrong with the Greek debt crisis is that an ideological smokescreen was used to bypass a complicated issue in democratic theory i.e. the social and political significance of public debt, including the allocation of burdens connected to it - with a power game among financial and governmental elites. More precisely, the ideological conception of public debt led to the wrong kind of politics for a democratic context-wrong insofar as the politics of public debt concentrated rather than diffused elite power. We then put forward a two-pronged approach to reform the politics of public debt in a democratic direction.

\section{Moralism and technocracy}

Let us begin with a thumbnail sketch of the Greek debt crisis. The Great Financial Crisis spread from the United States to

see Tucker 2018, discussed by Klooster 2020b. At any rate, despite the connection between monetary policy and public debt, the insights from this literature cannot be entirely taken over, given that there is a more direct link between fiscal policy and democratic representation.

${ }^{6}$ For an insightful, undogmatic and accessible discussion of the notion of ideology, see Finlayson 2016, chapter 3. 
Europe in 2009. Greece quickly became one of the most affected countries with several private banks close to bankruptcy. By 2010, Greek public finances had deteriorated to a degree such that a default on the country's public debt was imminent. ${ }^{7}$ An initial rescue package was agreed with the European Commission, the European Central Bank (ECB) and the International Monetary Fund (IMF) in 2010, with follow up agreements in 2012 and 2015. The rescue packages were conditional on Greece adopting an agenda of austerity, labour law liberalisation, and large-scale privatisation of public assets (as stipulated in Economic Adjustment Programmes and the Memorandums of Understanding between Greece and the Troika (European Commission 2019). The austerity component saw social services, public pensions, and overall economic activity drastically reduced for several years (Kivotidis 2018). ${ }^{8}$ The measures of the first and second bailout packages systematically shifted the structure of Greece's creditors between 2010 and 2015, allowing foreign banks to reduce their exposure to a Greek sovereign default (Roos 2019, chapters 1719). This shift was brought about by spending most of the bailouts on foreign debt service ${ }^{9}$ and through the programmes of the ECB for buying Greek government bonds ('SMP'). By 2015 , the ratio of private to public foreign holders of Greek public debt had been inverted from $80 \%$ private and $20 \%$ public to $20 \%$ private and $80 \%$ public, whilst the relative magnitude of domestically held public debt rose as well (see Roos 2019, 263268). It is worth noting that members of the IMF board already foresaw and criticized this shift in 2010 (Tooze 2018, 344). Thereby the costs in the event of a Greek sovereign default were shifted from (direct and indirect stockholders of) Northern European banks toward the European populations, in particular to the Greek population (especially those dependent on income

\footnotetext{
${ }^{7}$ From the beginning of the crisis public debt rose from $95 \%$ to $115 \%$ of GDP, and the budget deficit came close to $15 \%$ of GDP. In this context sales of Greek bonds spiked, as did the interest rates on them (Verde 2011: 144ff). At the time, it also emerged that Greece had previously manipulated their public finance statistics to hide the extent of its budget deficits. However, there is doubt about whether these numbers justify the concentration on sovereign rather than private debt at the centre of the crisis narrative (Tooze 2018, 13-15).

${ }^{8}$ The population was hit hard by the crisis. Disposable income fell by $40 \%$ on average between 2007 and 2014. Unemployment throughout the past decade stayed close to or above $20 \%$, whilst youth unemployment hovered closer to $75 \%$. The negative impact of the crisis on public health has been significant (Simou and Koutsogeorgou 2014).

${ }^{9}$ Roos notes that (2019: 267) "only 5 percent of the total international bailout funds actually went to Greek government expenditure; the remaining 95 percent went straight back to the country's bondholders".
} 
from wages or public assistance)-at this point Greek banks were most exposed to Greek sovereign bond risk-already suffering under the most drastic austerity programme in the history of the EU (see also Roos 2018, 238).

The debt crisis challenged the structure of Greek democracy and led to drastic changes in Greek politics. In the period until 2015, the debt crisis arguably had already shaken the foundations of the post-dictatorship order by strengthening the executive to the point that the legislative powers of the Greek parliament were in doubt (e.g. through rule by decree and the installation of an unelected expert government) and by conceding control over public finance at least partly to the Troika of creditors (Roos 2019,298-310; Kivotidis 2018). At the same time, political protests reached record levels (Karyotis and Rüdig 2018; Kouvelakis 2011), with at times multiple events per day across the country. The electoral victory of anti-austerity left alliance Syriza in January 2015, which ended the longstanding duopoly of the conservative (ND) and socialdemocratic (PASOK) parties, was poised to lead to a rejection of the bailout agreements between the Troika and Greece. In the late spring of 2015, the conflict came to a head. The Syriza government decided to hold a referendum on the question of whether to accept the terms proposed by the Troika for the third bailout package. Syriza had promised in their election manifesto not to accept the terms of the Troika. The terms were rejected in the referendum with $61,3 \%$ voting against the terms (at a turnout of ca. 62,5\%). However, shortly afterwards, the Tsipras government - under strong pressure from the Troika to either accept the terms or leave the Eurozone - agreed to the third bailout package under arguably worse conditions. Tsipras then resigned and called for elections, in which a Syriza government was returned to power. However, those parliamentarians of Syriza who rejected the deal had either split from the party or stood down, including the former finance minister Yannis Varoufakis. After their demise, the Tsipras government broadly worked with the terms set by the Troika despite relatively minor quibbles. The recent successes of primary budget surpluses (before debt service is taken into account) should not paper over the fact that wage levels have not yet reached pre-2009 levels in Greece (Hellenic Statistical Authority 2019; Romei 2018).

For the purposes of our critical exercise, it will be important to identify the notion of public debt that structured public debate during the Greek crisis. Our analysis of public discourse on this issue reveals a two-pronged notion. Public debt would be, ostensibly, an obligation incurred by a state that as such simply must be repaid (i) because it is a promise, and (ii) 
because failing to do so would lead to economic catastrophe for all involved, and especially the debtor state. Let us call (i) the moralising frame, and (ii) the technocratic frame for public debt. The discourses of the mainstream politicians likened the Greek public debt to private debt and focused either on grounding the obligation of Greece to pay on moral arguments or sought to portray decisions on Greek public debt, e.g. whether full or reduced repayment is required, as a form of technical administration to be determined by economic theory rather than politics. These discourses sought to provide normative orientations for how to deal with public debt that would float above the fray of politics. They were supposed to show that either moral or technical norms rather than political power shape how decisions about Greek public debt are made.

Our contention is that neither the moral nor the technical claim was epistemically tenable at the level of certainty at which it was uttered (which itself does not require us to offer alternative claims, as we shall see), nor was either claim in line with the actual practices of those putting it forward. If that is the case, there are at least two senses in which public debt is not what it seems, and so public debt discourse is ideological, in a pejorative sense of the term. ${ }^{10}$

To start off, let us observe how moralising and technocratic frames have different but complementary functions in the overall power struggles over public debt. Moralisation provides support for justifying payment obligations. Technocratic frames support a depoliticised approach to how obligations should be discharged. Moralising and technocratic frames are in a very close relationship, because moralist frames circumvent public discussion of payment obligations, the acceptance of which prepares the ground for using technocratic frames for the administration of payments that also circumvents public debate. More concretely, moralism masks the reality "that the norm of repayment is itself a pre-established political fact" (Roos 2019, 43), and is most effective at this occlusion against the background of the depoliticised repayment norm. Technocratic frames are instrumental to keeping sovereign

\footnotetext{
${ }^{10}$ Unlike most accounts of ideology, ours is an epistemic one, which we defend at some length in Prinz and Rossi 2017, Rossi 2019, Argenton and Rossi 2020. The rough idea is that if a political actor relies-consciously or not-on epistemically questionable narratives to buttress their position, then there is reason to consider their position ideological in the pejorative sense. And this is particularly worrisome when the ideological narrative protects and/or reproduces the power relations of the status quo, or reinforces the position of the strongest. While power asymmetries are not, strictly speaking, necessary for ideological distortion, in most real-world cases they are likely to be part of the picture.
} 
debt apolitical, as in "standard economic theory" repayment is "considered nonpolitical by definition", while "nonpayment is stigmatised as an irrational and explicitly political choice" (Roos $2019,43),{ }^{11}$ despite the fact that in mainstream economics accounts of debt the probability of non-repayment is discounted in the interest rate as a matter of course. ${ }^{12}$

The moralizing framing of the Greek sovereign debt crisis portrayed repayment obligations as categorical, playing on an analogy between the personal norm of keeping promises and the "pacta sunt servanda" idea which views agreements between states as similar to promises between individuals (or individual households). It tied the above-mentioned trope of private irresponsibility to ethno-cultural stereotypes of "Northern Saints" and "Southern Sinners" (Mathijs and McNamara 2015; see also Mylonas 2018; Kutter 2014; Kitromilides 2013; Vaara 2014). Moralizing narratives were so powerful that "[e]ven the potentially catastrophic stresses of the EU-wide contagion unleashed by Greece's fiscal insolvency and subsequent financial crisis could not dislodge the view that national problems of fiscal profligacy and weak competitiveness were the source of the problem" (Mathijs and McNamara 2015, 243).

The technocratic framing had two main themes: first, that the conditions under which Greece should be provided with liquidity would be set unilaterally by the experts and creditors. The following comments by German finance minister Wolfgang Schäuble illustrate this theme:

"The Troika has been asked by the European member states to discuss this [crisis], and every time the members meet, its own existence, and especially the IMF's involvement is discussed. The Troika has decided the governments of the countries in need of loan programmes should not participate in the negotiation because we trust in the institutions with the most expertise, with the most experience, and that know most of the facts. Those are, first, the European Commission [...] second, the very independent European Central

\footnotetext{
${ }^{11}$ The "there is no alternative" narrative adopted by powerful media to public debt repayment (see e.g. reporting on Argentina and Greece, Mercille 2013; Antoniades 2013) further bolsters the technocratic framing.

${ }^{12}$ What is more, standard approaches to portfolio management assume non-performing loans and, given the desirability of a certain amount of uncorrelated assets, even advises acquiring loans with a higher chance of non-repayment (Meyer 2018). We thank Eric Schliesser for pointing this out to us.
} 
Bank, and third, the most experienced institution, namely the IMF. These three know what is economically right. [...] The conditions the Troika sets cannot be approved by the European Parliament because the Troika has the sort of independent economic knowledge, the European Parliament lacks, to take the necessary decisions" (Schäuble 2012).

The second theme was that any rescue package would follow the logic of technical administration rather than politics. Schäuble's claim that the Greeks "can vote however they want, but whatever election result we have will change nothing about the actual situation in the country" summarises this theme succinctly (These technocratic themes were not limited to EU responses to Greece or public debt, but according to SanchezCuenca 2017, a wider trend of EU politics post-GFC). ${ }^{13}$

We are now in a position to see exactly why the framing of Greek public debt by the creditors-both for their domestic audiences and in their attempts to make their cases to the Greek debtors-was not what it seemed. The first problem has to do with the lack of alignment between creditors' discourse and their behaviour. This is true of both the moralising and the technocratic frame, though it is perhaps most evident in the former case, and most relevant too, insofar as a deceptive behaviour by those claiming the moral high ground is particularly callous. Decisions about public debt were framed as a matter of morality, or more precisely moral hazard, the idea being that one must not socialise debt if people live beyond their means (see e.g. examples in Mathijs and McNamara 2015). Yet actual decisions were made on the basis of political expedience and relative power of creditors and debtors, contrary to the morality tale, and also in contradiction to the technocratic frame's predictions (Whilst the fear of the socialisation of credit risk was mobilised in the discourse about "Northern saints" and "Southern sinners", the Troika's first two bailout packages brought about the socialisation of Greek debt through the back door of the ECB (see above). It was politically expedient for states home to the banks most exposed to a Greek default to rescue these private Northern European banks highly exposed to a default of the Greek state and Greek businesses. ${ }^{14}$ In other words, the moralised discourse was inconsistent on its own terms from the early stages of the

\footnotetext{
${ }^{13}$ See Ojala and Harjuniemi (2016) for a discussion of technocratic media narratives since the start of the GFC.

${ }^{14}$ In other words, to a considerable extent the Greek state's agreement to the bailout "rescued" investors in northern banks, not vice versa.
} 
process, when bailout packages were not allocated on the basis of minimising moral hazard and systemic risks to the European economy, but rather to favour the politically strongest actors ${ }^{15}$ (see Herzfeld 2016a; 2016b; Kitromilides 2013). However, the moralisation and technocratic narratives stuck anyway. Even when Germany turned a profit on the Greek bailout and the ECB profited from trading Greek bonds to Greece both frames remained in place (Roos 2019, 270, 285). ${ }^{16}$

In addition to being inconsistent with the actual practices of their supporters, both frames are also epistemically untenable, at least relative to the degree of conviction with which they were advocated. In the case of the moralising frame, this is exemplified most clearly by this widely publicised remark by German Chancellor Angela Merkel, notable for its transparent appeal to commonsensical bourgeois respectability and morality: "One should simply have asked a Swabian housewife [...] She would have told us her worldly wisdom: in the long run, you can't live beyond your means" (Merkel quoted in Bennhold 2010). ${ }^{17}$ While, as we will see shortly, there is little agreement among economists about the exact workings of public debt within an economy, there is no doubt about the fact that a household budget is not a good analogy to a state's balance sheet (Farmer and Zabczyk 2018).

The epistemically untenable character of the technocratic narrative is highlighted by the fact that the supposed consensus among economists about the response to the European public debt crises does not exist. In (international) political economy and heterodox economics, the supposed consensus view on debt repayment and austerity is actually highly contested (Blyth 2012). And even within mainstream macroeconomics there are fundamental disagreements on the likely effects of austerity on states' balance sheets (compare Alesina et al. 2019; Alesina and Ardagna 2011; Reinhart and Rogoff 2010 to Krugman 2015; Wren-Lewis 2015). In fact, in the case of the Troika, factions within the IMF opposed extending a loan to Greece under the

15 Note also that the "socialization" of risk coincided with the consolidation of power of the ECB over Greece (Roos, 247-248), becoming its biggest bondholder in the short term in 2011.

${ }^{16}$ Alexander Douglas has shown that the moralist argument for balanced budgets is self-defeating. In as far as the state is ultimately responsible for the viability and the moral standing of the institution of debt, under capitalism its legitimacy is tied to the provision of sufficient debt resources (Douglas 2016, 152-3).

17 This is not an unusual occurrence, as the reliance on empirically incorrect "folk theories" of money by central banks and governments during the GFC shows. The public debunking of, and move away from, such folk theories in the case of the Bank of England suggests increased pressure on such tools for floating above politics (Braun 2016). 
conditions proposed by the ECB and EC due to concerns about the sustainability of the debt. ${ }^{18}$ Even the ranks of IMF technocracy broke when the austerity package was found to be ill-judged and to engender socially unacceptable distributions of burdens (Roos 2019: 269-271). ${ }^{19}$

Moralisation and technocracy are political strategies whose appeal stems from their claim to float above the partisanship that characterises politics and to possess extra-political foundations and uncontroversial validity. As we have seen, however, moralisation and technocracy do not possess such uncontroversial validity. Rather than providing the most morally sound and rational approach to public debt, the main function of these frames is to mask how political actors actually deal with public debt, as we will see shortly.

Now, if mainstream public discourse on debt is not what it seems, what is it? To answer this question, it may be useful to begin from an important distortion engendered by both the moralising and the technocratic frame. Both moralisation and technocracy treat states as unitary actors, which is a distortion, given that different groups within the state are affected in very different ways by public debt, and are responsible to a very different degree and in different ways for the extent of public debt. Indeed, we want to show that the politics masked by the two frames is a form of bellicose oligarchy-little short of a class war in service to very particular interests, as demonstrated by some of the most authoritative reconstructions of the events in Greece 2010-2018 (Roos 2019; Roufos 2018). ${ }^{20}$ Simplifying somewhat, we maintain that this kind of politics of public debt is an instrument for shifting around power amongst governmental and financial elites and sidestepping the perspective of the vast majority of the affected populations of debtor and even creditor states-a problem of power concentration, not of moral standing, as we will see below. ${ }^{21}$

\footnotetext{
${ }^{18} \mathrm{An}$ ad-hoc change of the IMF rules introduced through the back door was necessary for the IMF to participate in the Troika (Tooze 2018, 336, 344).

${ }^{19}$ Other critical notes from within broadly technocratic views include Buchheit and Gulati (2010); Modi (2015). In hindsight, high level EU bureaucrats question their approach (Buti 2020).

${ }^{20}$ Realpolitik is after all typically the politics of treating the state as a unitary actor, on behalf of which elite politicians take decisions in back chambers.

${ }^{21}$ Our argument is compatible both with the view that contemporary liberal-democratic states structurally tend toward "civil oligarchies" (see Winters 2011) and the view that oligarchic tendencies are the result of elite capture of a state that is not already committed to wealth accumulation as the highest good. Thanks to Andrew Scerri for raising this point.
} 
More specifically, the mechanism that structures the real politics of public debt can be understood as composed of two related types of reduction to mere power relations, beyond the reach of democratic politics: (i) a reduction of the force of the loan agreement to the power relations between debtors and creditors, and (ii) an identification of debtors and creditors with financial and governmental elites.

We can illustrate that point by returning to our case study of the Greek crisis. The oligarchic mechanism can be schematically reconstructed as follows. A combination of market pressure from a cartel of lenders (Roos 2019, 229, 232, 283-4), political pressure from public ("official") lenders of last resort (in particular the European Commission), and the procreditor forces in Greek society (even within the left-wing Syriza government which enforced the "repayment norm" under duress, i.e. with an explicit threat of causing bank runs and other forms of social disorder). This prevented unilateral Greek default and structured the unfolding of the Greek public debt crisis. To get a sense of the concrete implications of this course of events, consider that, as a result of the agreement between the Greek state and the Troika, at one point taxes on the poorest rose by $333.7 \%$, in the context of a mere $9 \%$ overall increase (Roos 2019, 271). Elections and even the much-touted 'Oxi' referendum - in which citizens soundly rejected the terms of the Troika's bailout-made no material difference to the outcome from the point of view of the creditors, in line with the pronouncements of the then German finance minister we just reviewed. Bargaining within this elite actor constellation is what drives the actual politics of public debt, in spite of the moralistic and technocratic rhetoric that would have the public believe otherwise. ${ }^{22}$

\section{How to politicise public debt democratically}

In the previous section we painted quite a grim picture. Here we will outline an alternative politics of public debt-one that politicises public debt all the way down in a democratic manner. But before we can do so, we need to explain why such an alternative is even possible, and why it is required. Indeed,

22 The realist literature treats beliefs, political discourse, and even philosophical arguments as possible loci of ideological distortion (Cozzaglio 2020, Beetz and Rossi 2017, Prinz and Rossi 2017, Rossi and Argenton 2020). Our discussion here is compatible with all of those approaches. Political discourse can be criticized for being ideological regardless of whether it is successful in persuading a population, so we can remain neutral on how effective the rhetoric of the Troika was, for example (also because such rhetoric clearly had completely different aims when directed at the Northern European public as opposed to the Southern one). 
someone sympathetic to an old-fashioned version of political realism may welcome our unveiling of the Realpolitik of public debt, and think that our unmasking more or less completes the task of political theory: we have removed the fig leaves of moralism and technocracy, and laid bare what politics is all about, namely (elite) power. ${ }^{23}$ This would mean that there is no normative conversation to be had, except one about the instrumental rationality of incentives and costs. Isn't that what (re-)politicising debt means? No. We want to show that, somewhat paradoxically, this hard-nosed understanding of the politics of public debt misses important opportunities for politicisation, at least if we understand politics in context, which in the case at hand means that democratic aspirations are a necessary element of politics. In other words, and despite appearances, oligarchic Realpolitik does not politicise public debt all the way down, at least not in a democratic context.

To carve out space for our alternative proposal we need to first take a step back and understand the sense in which our account of politicisation must be context-sensitive. Here we rely on Bernard Williams' (2005) by now famous realist account of the normativity internal to politics. In a nutshell, Williams maintains that normative political questions should not be addressed by working out the implications of pre-political moral commitments, but rather by working out what it means to meet the "Basic Legitimation Demand" in a particular context. That is to say, polities must provide order in ways that "make sense" to those over whom political power is exercised. It's important to note here that making sense is not an acceptability or accessibility condition grounded in a moral conception of the person similar to those found e.g. in the public reason literature (Rossi 2013), but rather a requirement derived from a conceptual distinction between politics and suspended warfare, or brute coercion: politics inhabits a distinctive sphere between quasi-voluntary cooperation and brute coercion, and we know that we are in a political condition when the order at hand makes sense to the relevant population. A further condition for the Basic Legitimation Demand to be met is that subjects' perceptions of the power are not conditioned by the power itself, i.e. that it is not ideologically distorted (an account of ideological distortion different from the one we use here). ${ }^{24}$

\footnotetext{
${ }^{23}$ The currently ascendant legal theory of finance (Pistor 2013) may be read as pointing in this direction. On the other hand, it also shows the normative discretion afforded by the entanglement of politics and financial markets.

${ }^{24}$ Williams calls this the "Critical Theory Principle". For a discussion and exposition of this position see Williams 2002, 219-232. For our own reservations about this view, and our own extended discussion of our
} 
Crucially, subjects' expectations of what is required for political power to make sense to them will vary with context. For example, Williams $(2005,8-12)$ maintains that in a modern context only a liberal order would make sense. We will not engage with that claim directly here. However, the general structure of realist context-dependence is key for our argument. The point we wish to highlight is simply that any effective politicisation of a practice-such as public debt-with the potential to affect a polity's ability to meet the Basic Legitimation Demand will have to be formulated in a contextsensitive way.

So our next step will be to work out the context-sensitive desiderata of a realist politicisation of public debt. The relevant context, as we noted, is that of contemporary democratic politics in the Eurozone. In which case the abstract Williamsian idea of the exercise of power making sense to those affected by it takes on a more specific connotation. Williams defines making sense as the recognition of the political order as authoritative in the relevant-in our case democratic - context (Williams 2005, 10-11). This recognition depends on those holding power having "something to say" to those over whom power is exercised, where that something goes "beyond the assertions of power" (Williams 2005, 11). We have seen that, in the case of public debt, ideological distortion takes the form of masking actual political practices with the frames of technocracy and moralism. The question then becomes: would removing those frames be enough for the politics of public debt to make sense to those affected? We claim that it wouldn't, and that is why there is both room and need for an alternative politics of public debt. The key to that claim is the contextualism we flagged earlier. Recall the point about the oligarchic character of the Realpolitik of public debt: the actors at play are exclusively governmental and financial elites asserting their power. Our contention is simply that, once unmasked, this reality cannot be expected to make sense as going beyond the assertion of power in a democratic context, insofar as we take democracy to at least require a significant level of diffusion of power beyond the ranks of the elite (note that, importantly, a policy can be acquiesced to without the overall order making sense). The Realpolitik of public debt is the wrong kind of politics for the current democratic context, as it leads to a consolidation of elite power which clashes with the promise of democracy to disperse power.

To understand that claim in the context of our argument we can turn to recent developments in realist democratic theory.

preferred alternative, see Prinz and Rossi 2017. 
The general idea of interest here is that we can understand democracy in a 'negative' (Bagg 2018b) or 'anti-oligarchic' way (Arlen \& Rossi 2020). This realist understanding of democracy is power-centric, and thus not grounded in abstract moral notions such as freedom or equality (Christiano 2008), nor in some epistemic ideal (Estlund 2008, Landemore 2012). As Bagg puts it, "the value of each of these crucial democratic institutions is best understood in terms of the power it denies to various elites, and which is thereby retained by various groups of ordinary citizens." (2018b, 892). This is a realist understanding of the legitimacy of democratic institutions because it is powercentric: it is grounded in the political as opposed to the moral characteristics of democracy, or in political as opposed to moral values. ${ }^{25}$ The oligarchic characteristics of the Realpolitik of public debt, then, are why we need a different way politicise public debt: we need a politics of public debt that does not require the cover of ideological narratives to make sense to democratic citizens. Put another way: moralism and technocracy make sense but their making sense doesn't count as it is ideological, whereas Realpolitik would not make sense (regardless of whether it may be acquiesced to). ${ }^{26}$

To translate that point into a set of desiderata for a democratic politics of public debt, we may say that such a politics must make sense after non-ideological public scrutiny. In order to do so, we posit that it should effectively disperse power among those over whom it is exercised. Such a democratic politics would politicise public debt all the way down in a non-moralistic way, while avoiding the perils of Realpolitik.

At the very least, a democratic politics of public debt must neither turn out to be ideologically distorting nor further the concentration of elite power. The more a politics of public debt meets these desiderata, the better its chances are of avoiding prevarication by private financial actors or by other states.

Fulfilling the desiderata would principally depend on two related conditions, which in turn should be the basis for more concrete policy proposals. We can only formulate the conditions in rather general terms here: especially in light of our

25 There is a growing literature on realism and the distinction between moral and political values, and we cannot do it justice here. Our position rests on the idea of political values articulated by Jubb and Rossi (2015), Sleat (2016), and Jubb (2019).

${ }^{26}$ Note that this contextualist move is not a way to smuggle in a moral presupposition in order to resist the imperatives of Realpolitik. Rather, it is a way to ensure that a polity actually meets its basic legitimation demand, rather than just having the appearance of meeting it. On how realist legitimacy navigates the difficult passage between moralism and Realpolitik see Sleat 2014. 
methodological commitments, we eschew detailed blueprints and maintain that concrete implementation should remain a matter of democratic political struggles. ${ }^{27}$ The two conditions are (i) the effectiveness of dispersing public debt-related power and (ii) the quality of deliberation on public debt. The hope is that if the two desiderata are co-realised, a revised conception of public debt which emphasises that public debt is a means to serve public purposes (and not the other way around) may develop. ${ }^{28}$

To fulfil (i), the affected public(s) at large needs to bring public-debt related power under democratic control. This control needs to be appropriate to the debt's importance for democratic legitimacy. ${ }^{29}$ For this control to be effective, it needs to take a wide view of public-debt-related power. This view would not only need to incorporate the relationship between creditors/lenders and debtors/borrowers but also would need to reckon with the importance of public debt as safe assets, as has been shown in debates about monetary policy and (shadow) banking (Braun 2018; Sgambati 2019), 30 and with how states are increasingly using public debt to pursue policy goals through private market actors, which in turn gives these actors power that is of limited public accountability (Braun, Gabor \& Hübner 2018).

The effectiveness of dispersing public debt-related power depends, to a large extent, on popular control over setting rules for entering into debt agreements and for issuing loans (underwriting), and would also need to extend to the review of the status of present loans. This would include the power to hold accountable those who decided to lend or borrow, at the very least to investigate to what extent these decisions were furthering the public purposes of the polity-that is to say, purposes that make sense to the citizenry.

Another important aspect of public control is the role of what have come to be known as official creditors-chiefly the International Monetary Fund (IMF) and the World Bank. Here our realist democratic approach suggests a rejection of international organisations which seek to float above the political fray (typically by relying on technocratic narratives). In

\footnotetext{
${ }^{27}$ For a detailed discussion of this methodological point, see Rossi 2019.

${ }^{28}$ See e.g. the related lines of argument brought forward for rethinking central banking by Braun and Downey (2020).

${ }^{29}$ In the EMU, public debt can quickly affect the ability of the state to deliver order and stability and the domination or usurpation of the democratic sovereign by private financial actors. This is arguably not the case in the most powerful monetarily sovereign countries (see Kelton 2020).

${ }^{30}$ The context is now a global economy more affected by the balance sheets of the big banks than by the balance sheets of each state.
} 
other words, we should try to roll back the influence of these appendages of the state system that have taken on a life of their own as agents of elite interests.

The effectiveness of public control in turn considerably depends on making public debt a mainstay of public concern rather than a topic reserved for moments of crisis. However, as the Greek crisis exemplifies, actual public discussion about public debt is either ideologically distorting or inappropriate for the democratic context and has barely advanced beyond the false choice between depoliticisation (moralism and technocracy) and the Realpolitik of public debt.

(ii) Deliberation must put the public at large into a position to non-ideologically evaluate whether the regime of public debt (either in the role of debtor or creditor or both) furthers public purposes or not (and hence supports or threatens meeting the BLD). The point is not that deliberation is needed because it can neutralise power-it cannot, as ample evidence on motivated reasoning shows (Bagg 2018a). ${ }^{31}$ Deliberation is needed because the selection of public debt policies must be both public (in a non-ideologically distorted way) and open-ended. But, given the poor quality of current public discourse on debt, to formulate a proposal for deliberation on public debt we have to start more or less from scratch. ${ }^{32}$

To begin with, judgments and decisions made about matters of public debt should be presentable (and justifiable) in the terms that relate to the purposes of the polity as expressed by collective actions of citizens rather than, as we have seen above, in ideologically distorting moralist and technocratic terms that mask elite interests. Existing policies on public debt need to be re-examined and reframed with regard to their effect on, and compatibility with, these purposes. ${ }^{33}$ In as far as institutions like the IMF have in the past set the purposes and offered justification for their measures in predominantly technocratic terms, we expect that their legitimacy would be severely challenged by a democratic politics of public debt that meets our desiderata (Clegg 2013), in line with our criticism of official creditors in (i) above.

Deliberation on public debt should further have recourse to

31 However, congruently with the realist democratic theory sketched above, one may hope that deliberation will at least contribute to the dispersion of power.

32 There have been attempts to flesh out such ideas in the related field of monetary policy (e.g. Best 2016; Klooster 2020a; Kloster and Fontan 2019) which, however, often remain most interested in improving deliberation inside central banks or in the political institutions that draw up their mandates.

${ }^{33}$ None of the above guarantees that future debates about public debt will not turn out to be dominated by moralism or technocracy. 
(but not necessarily be directed by) the best available evidence which will be a combination of e.g. the known factors (global financial architecture etc.) and less certain matters of public finance ("known unknowns"). ${ }^{34}$ That is to say, technocratic discourse that seeks to obscure that the issue is not scientifically settled is unsuited to proper public deliberationa point familiar from debates on the role of science in public reason, but grounded not in ideals of equal respect for fellow citizens, but in the form of ideology critique we have offered.

Our emphasis on the importance of deliberative quality for a democratic politics of public debt should not be mistaken for a proposal to turn the democratic politics of public debt into deliberative democracy in a narrow, technical sense, which is only partly compatible with our realist commitments due to its tendency to model politics on a quest for finding rational consensus. We are rather proposing a focus on the deliberative quality of the political processes at large (Mansbridge et al. 2012). Taking some inspiration from deliberative systems theorists (e.g. Bächtinger and Parkinson 2018), we envisage that a democratic politics of public debt would contain a combination of different forms of activism, protest, rhetorical confrontation, and public information campaigns. The more narrowly deliberative forms of exchange of reasons would only play a minor role, for realists still have ample reason to be cautious about the promises of deliberation (Bagg 2018a, Cross 2019; classically also Young 2001).

In our example case of the EMU and Greece, deliberation about public debt would need to come to terms with, amongst other things: the systemic importance of (limited) public debt for the EU project (from Maastricht to the Fiscal Compact), the structural tensions between different members of the EMU, the gap between political and monetary integration, the transnational dimension this adds to concerns with democratic legitimacy (Abizadeh 2008; Verovsek 2017), the questioning of the view of the state as a unified actor, the consequences of debt service for different groups, and the place of public debt in the wider dynamics of capitalist economies. ${ }^{35}$

\footnotetext{
${ }^{34}$ See Pistor 2013 for some reservations about a non-elastic legal framework for financial markets

35 If these terms sound so complicated as to lead to doubt about the public's ability to understand them, that reinforces the need for broader public education on political economy and public finance (which, tellingly, is barely a part of mainstream economics). At any rate, we envisage that such a public discussion may proceed along lines such as those: the rough consensus among economists was that Greek debt is unsustainable because Greece imports much more than it exports, and this in turn because the productivity of capital and labor grows less than their remuneration (profits and wages). If this is the prerequisite to
} 
Increased attention paid to, and increased popular control, over public debt may spark interest in the political and social value of debt and credit, the responsibility of creditor and debtors for making the institution of debt and credit politically valuable (see Douglas 2016; Orléan 2014). ${ }^{36}$ While Alexander Douglas (2016) has offered a compelling argument for the institution of debt which is all things considered a consequentialist case for productive lending and against nonproductive, "extractive" lending, we maintain that the political value of debt, in particular public debt, cannot be reduced to productiveness but has to be anchored in the contribution debt makes to democratic legitimacy. Such interest may spill over into the examination of e.g. the public and (public-)private money creation, and the public basis of the value of currency (see Hockett and Omarova 2017; Hockett 2018; Ingham 2004). Indeed, understanding how such institutions are interwoven with the state is an important step toward making the monetary system-which is arguably increasingly interdependent with the financial system more broadly speaking (Pistor 2013) - fit for democracy: the public should be able to exert some control over the system, which has arguably been a blind spot of much recent political philosophy and critical theory (Klein 2020). Questions remain, inter alia, about the viability and even the desirability of public debate on

balance the books, we need to lower wages and profits and increase productivity (say). Some distinctions are in order here: (i) not in all sectors productivity and remuneration differ in the above way, so the first thing to do is to identify problem sectors and act on them; (ii) the imbalance with foreign countries is not a one-way phenomenon: what can creditor countries (especially those in the EMU) do to encourage adjustment? (iii) Taking into account the cost of adjustment in terms of individual welfare, capacity for democratic action, economic contraction, contagion to other countries, etc. should Greece declare default, make a haircut, be subsidized, or what else? (This is the most complex part of the calculation.) At this point the purely political and normative discourse begins: which groups (states, financial organizations, workers, age groups, etc.) have to bear the adjustment costs, and to what extent? That hypothetical sketch should also clarify that there is both a role for the economist's expertise in our politicized model and space for questioning the priorities of the economic constitution at the heart of the EMU. (We thank Mario De Cristofaro for discussion of this scenario.) We envisage that such discussions could take place both at the national level and at the European level, with the latter being the crucial one, given the parties involved. Fleshing out the institutional details of how such a debate may take place would require another paper. For a sense of our view of what European-level legitimate political activity requires, see Beetz and Rossi 2017.

${ }^{36}$ Preiss 2018 makes a related argument about the trade-off between freedom and availability of credit. 
matters of considerable theoretical complexity (Klooster 2020a, 593) - and the answers will vary wildly depending on context. But, at the limit, it may just be that complex economic institutions with the power to affect states' basic legitimacy need to be made understandable to the wider public, or they cannot coexist with democracy. ${ }^{37}$

To be sure, our approach is not exhaustive, nor can we promise it will solve the problem of the democratic legitimacy of public debt in two fell swoops. ${ }^{38}$ To name the most important missing piece, we have not sufficiently touched on the issue of the power of private financial actors, chiefly because of our focus on democratic politics. Yet it is important to at least acknowledge the importance of those actors: for instance, "creditworthiness" (and its importance) is set by financial markets and practically uninfluenced by the electorates of affected states. However, as Roos (2019) has shown, markets "alone" 39 would not have the power to enforce the current global public debt architecture that discourages default (either as repudiation of debt or as restructuring) without state backing, so arguably our focus can also be justified strategically. At any rate, our approach directly attacks two of the three pillars of the current regime - the hold of national elites and the position of official creditors - and thus at least indirectly affects the third, financial markets, including rating agencies (e.g. through national legislation and through potential changes to the other two pillars). ${ }^{40}$ This means that the democratic politics of public debt would have considerable wherewithal over private creditors.

\section{A methodological conclusion}

We have argued that the prevailing discourses on public debt are ideological: moralism and technocracy mask a politics

\footnotetext{
${ }^{37}$ For a more general argument on the problem of theoretical complexity in democracy see Bertram (1997).

${ }^{38}$ Another challenge for our approach would be to determine how a democratic politics of public debt would handle disputes between "debtor" and "creditor" states. A democratic politics of public debt would need to be particularly careful when making decisions that would on reasonable expectation have the potential to undermine the ability of a debtor state to maintain its democratic legitimacy. This returns us to questions about monetary solidarity which plague the EMU (see e.g. Schelkle 2018).

${ }^{39}$ Markets cannot strictly-speaking act alone, but always depend on the state for enforcement or backstop.

${ }^{40}$ The rough idea here would be to ring fence public debt issues as far as possible within domestic law, and to specify very demanding underwriting requirements.
} 
of public debt that is little more than a power game between elites. We have also seen that this is not a form of legitimate democratic politics, and so we put forward two ideas for how to ameliorate the situation.

In conclusion, it may be worth saying a little more about why our recommendations are so tentative-a limitation that, we maintain, is at least in part due to our methodological stance. An obvious methodological lesson from the preceding discussion concerns the perils of ideology in political argument, both public and academic. We trust those have been expounded sufficiently in the body of the paper. However, an extension of that lesson may be worth highlighting here, namely a general caution about the limits of theory, and its inability to float above the fray of politics-much like the common sense and scientistic overreach we have diagnosed in the moralistic and technocratic frames, respectively. ${ }^{41}$ So the realist moral of the story here is that when theory or common sense try to invade the domain of politics and float above it they are at high risk of ideological distortion. On issues such as public debt our philosophical arguments can join the political fray but cannot claim to transcend it. Besides, the very contextsensitivity that drives our argument for politicising public debt all the way down cautions against theorising policy blueprints in quasi-algorithmic abstraction from local realities. In other words, if we are serious about politicising financial power in a democratic way, we should heed the realist call for philosophical modesty: in addition to reminding ourselves that the political philosopher is always socially situated, the lesson here is that a lot of the terrain often claimed by political philosophy should be left to the rough and tumble of politics.

\section{Acknowledgements}

We would like to thank Mario De Cristofaro, Alexander Douglas, Andrew Scerri, and Eric Schliesser for providing insightful comments on the manuscript. We would also like to thank the audience at the The Political Economy of Debt after the EuroCrisis: Normative and Empirical Perspectives workshop at University of Amsterdam, with particular thanks to Gordon Arlen for organizing the workshop. Janosch Prinz would like to thank the Leverhulme Trust for supporting his research for this paper with an Early Career Fellowship (ECF-2016-227). He would also like to thank the York-Maastricht Partnership for

${ }^{41}$ Which is not to say that there isn't also political overreach, either in the Realpolitik sense described above, or in the more subtle ways examined in Aytac 2020. 
supporting his ongoing research. Enzo Rossi's research for this essay was supported by the Dutch National Science Organisation's (NWO) Vidi project "Legitimacy Beyond Consent" (grant n. 016.164.351).

\section{References}

Abizadeh, Arash. 2008. Democratic Theory and Border Coercion: No Right to Unilaterally Control Your Own Borders. Political Theory 36, no. 1, 37-65.

Alesina, Alberto F. and Silvia Ardagna. 2009. Large Changes in Fiscal Policy. Taxes versus Spending. National Bureau of Economic Research Working Paper 15438, available at http://www.nber.org/papers/w15438.

Alesina, Alberto, Carlo Favero and Francesco Giavazzi. 2019. Austerity. When It Works and When It Doesn't. Princeton and Oxford: Princeton University Press.

Antoniades, Andreas. 2013. At the Eye of the Cyclone. Greek Crisis in the Global Media. In Greece's Horizons. Reflecting on the Country's Assets and Capabilities, edited by Pantelis Sklias and Nikolaos Tzifakis, 11-25. Dordrecht: Springer.

Arlen, Gordon and Enzo Rossi. 2020. "Must Realists Be Pessimists About Democracy?" Moral Philosophy and Politics, forthcoming.

Aytac, Ugur. 2020. "On the Limits of the Political". Constellations, forthcoming.

Bächtinger, André and John Parkinson. 2018. Mapping and Measuring Deliberation. Towards a New Deliberative Quality. Oxford and New York: Oxford University Press.

Bagg, Samuel. 2018a. “Can deliberation neutralise power?" European Journal of Political Theory, 17(3), 257-279.

Bagg, Samuel. 2018b. "The Power of the Multitude: Answering Epistemic Challenges to Democracy." American Political Science Review, 112(4), 891904

Beetz, Jan Pieter, and Enzo Rossi. 2017. The EU Legitimacy Deficit in a Realist Key: multilateral governance, popular sovereignty and critical responsiveness. Transnational Legal Theory, 8, pp.22-41.

Bennhold, Katrin. 2010. "In Greek Debt Crisis, a Window to the German Psyche." May 4, $2010 . \quad$ Available at: https://www.nytimes.com/2010/05/04/business/global/.

Bertram, Christopher, 1997. "Political Justification, Theoretical Complexity, and Democratic Community". Ethics, 107, pp.563-583.

Best, Jacqueline Technocratic Exceptionalism: Monetary Policy and the Fear of Democracy." International Political Sociology. Vol. 12, No. 4, 2018, pp. 328-345.

Best, Jacqueline. 2016. "Rethinking Central Bank Accountability in Uncertain Times," Ethics and International Affairs 30(2), 215-232.

Blyth, Mark. 2012. Austerity. The History of a Dangerous Idea. Oxford: Oxford 
University Press.

Buchheit, Lee C., and G. Mitu Gulati. 2010. "How to Restructure Greek Debt." Duke Law Working Paper 47. Duke University, Durham, NC.

Braun, Benjamin. 2016. "Speaking to the people? Money, trust, and central bank legitimacy in the age of quantitative easing." Review of International Political Economy, 23:6, 1064-1092.

Braun, Benjamin. 2018. "Central banking and the infrastructural power of finance: the case of ECB support for repo and securitization markets". Socio-Economic Review, doi: 10.1093/ser/mwy008.

Braun, Benjamin, Gabor, Daniela \& Hübner, Marina. “Governing through financial markets: Towards a critical political economy of Capital Markets Union." Competition \& Change, 22(2), 101-116.

Braun, Benjamin and Downey, Leah. Against Amnesia. 2020. "Re-imagining Central Banking". Council on Economic Policy Discussion Note No.2020/1.

Buti, Marco. 2020. "Economic policy in the rough: A European journey." Centre for Economic Policy Research Policy Insight No. 98.

Christiano, Thomas. 2008. The Constitution of Equality. Oxford: Oxford University Press.

Clegg, Liam. 2013. Controlling the IMF and World Bank. Basingstoke: Palgrave Macmillan.

Cozzaglio, Ilaria. 2020. "Can Realism Save US from Populism? Rousseau in the Digital Age." European Journal of Political Theory, https://doi.org/10.1177/1474885120906928

Cross, Ben. 2019. "Deliberative systems theory and activism." Critical Review of International Social and Political Philosophy, online first https://doi.org/10.1080/13698230.2019.1584842.

Douglas, Alexander X. 2016. The Philosophy of Debt. London and New York: Routledge.

Dyson, Kenneth. 2014. States, Debt, and Power. 'Saints' and 'Sinners' in European History and Integration. Oxford and London: Oxford University Press.

European Commission. 2019. Financial Assistance to Greece. Information on the enhanced surveillance framework for Greece. Overview of the ESM stability support programme and previous programmes. https://ec.europa.eu/info/business-economy-euro/economic-and-fiscalpolicy-coordination/eu-financial-assistance/which-eu-countries-havereceived-assistance/financial-assistance-greece en\#taskforceforgreece, last accessed 20 July 2019.

Farmer, Roger E. A. and Pawel Zabczyk. 2018. "The Household Fallacy." London: National Institute of Economic and Social Research. NIESR Discussion Paper No. 487

Finlayson, Lorna. 2016. An Introduction to Feminism. Cambridge: Cambridge University Press.

Frieden, Jeffry and Stefanie Walter. 2017. "Understanding the Political Economy of the Eurozone Crisis." Annual Review of Political Science 20, no. 1, 371-390. 
Harjuniemi, Timo. 2019. "Reason Over Politics." Journalism Studies 20, no. 6, 804-822.

Hellenic Statistical Authority. 2019. Press Release. Fiscal Data for the Years 2015-2018.

Available

at https://www.statistics.gr/en/statistics?p p id=documents WAR publica tionsportlet INSTANCE qDQ8fBKKo4IN\&p $p$ lifecycle $=2 \& p \quad p$ state $=$ nor

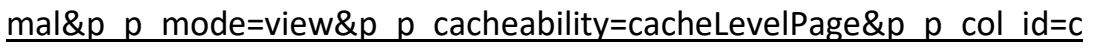
olumn-

$2 \& p \_$col count $=4 \& p$ p col pos $=1 \&$ documents WAR publicationspo rtlet INSTANCE qDQ8fBKKo4IN javax.faces.resource=document \& docu ments WAR publicationsportlet INSTANCE qDQ8fBKKo4IN In=downloa dResources\& documents WAR publicationsportlet INSTANCE qDQ8fB KKo4IN documentID=365781\& documents WAR publicationsportlet IN STANCE qDQ8fBKKo4IN locale $=$ en

Herzfeld, Michael. 2016a. "The Hypocrisy of European Moralism, part 1." Anthropology Today 32, no. 1, 10-13.

Herzfeld, Michael. 2016b. "The Hypocrisy of European Moralism, part 2." Anthropology Today 32, no. 2, 10-13.

Hockett, Robert C. and Saule T. Omarova. 2017. "The Finance Franchise." Cornell L. Rev. 102, no. 1143, http://dx.doi.org/10.2139/ssrn.2820176

Hockett, Robert C. 2018. "Rousseauvian Money." Cornell Legal Studies Research Paper Series No. 18-48, http://dx.doi.org/10.2139/ssrn.3278408.

Ingham, Geoffrey. 2004. The Nature of Money. Cambridge: Polity.

Jubb, Robert. 2019. "On what distinctly political normativity is." Political Studies Review 17(4): 360-369.

Jubb, Robert and Rossi, Enzo. 2015. "Political norms and moral values." Journal of Philosophical Research 40: 455-458.

Karyotis, Georgios and Wolfgang Rüdig. 2018. "The Three Waves of AntiAusterity in Greece 2010-2015." Political Studies Review 16, no. 2, 158169.

Kelton, Stephanie. 2020. The Deficit Myth. John Murray: London.

Kitromilides, Yiannis. 2013. "Stories, Fables, Parables, and Myths: Greece and the Euro Crisis, Toward a New Narrative." Journal of Economic Issues 47, no. 3, 623-638.

Kivotidis, Dimitrios. 2018. "The Form and Content of the Greek Crisis Legislation." Law and Critique 29, 57-81.

Klein, Steven. 2020. "The Power of Money: Critical Theory, Capitalism, and the Politics of Debt". Constellations 27, 19-35.

Klooster, Jens van 't. 2018. "Democracy and the European Central Bank's Emergency Power." Midwest Journal of Philosophy 42, 270-293.

Klooster, Jens van 't. 2020a. "The Ethics of Delegating Monetary Policy." The Journal of Politics 82 (2), 587-599.

Klooster, Jens van 't. 2020b. “Book Review. Unelected Power: The Quest for Legitimacy in Central Banking and the Regulatory State, Paul Tucker. 
Princeton University Press, 2018, 656 pages." Economics \& Philosophy, doi:10.1017/S0266267119000300

Klooster, Jens van 't and Fontan, Clement. 2019. "The Myth of Market Neutrality A Comparative Study of the European Central Bank's and the Swiss National Bank's Corporate Security Purchases." New Political Economy, DOI: 10.1080/13563467.2019.1657077

Kouvelakis, Stathis. 2011. "The Greek Cauldron." New Left Review 72, 17-32.

Krugman, Paul. 2015. The Austerity Delusion. The Guardian Long Read, available at https://www.theguardian.com/business/nginteractive/2015/apr/29/the-austerity-delusion.

Kutter, Amelie. 2014. "A catalytic moment: The Greek crisis in the German financial press." Discourse \& Society 25, no. 4, 446-466.

Mansbridge, Jane, James Bohman, Simone Chambers, Thomas Christiano, Archon Fung, John Parkinson, Dennis F. Thompson and Mark E. Warren. 2012. A systemic approach to deliberative democracy. In Deliberative Systems. Deliberative Democracy at the Large Scale edited by John Parkinson and Jane Mansbridge, 1-26. Cambridge: Cambridge University Press.

Matthijs, Matthias and Kathleen McNamara. 2015. "The Euro Crisis' Theory Effect: Northern Saints, Southern Sinners, and the Demise of the Eurobond." Journal of European Integration 37, no. 2, 229-245.

Mercille, Julien. 2013. “European Media Coverage of Argentina's Debt Default and Recovery: distorting the lessons for Europe." Third World Quarterly 34, no. 8, 1377-1391.

Meyer, Marco. 2018. "The Ethics of Consumer Credit: Balancing Wrongful Inclusion and Wrongful Exclusion." Midwest Studies in Philosophy, https://doi.org/10.1111/misp.12095

Mody, Ashoka. 2015. "The IMF's Big Greek Mistake." Bloomberg View, April 21, 2015.

Mylonas, Yiannis. 2018. "The 'Greek crisis' as a middle-class morality tale: frames of ridicule, pity and resentment in the German and the Danish press." Continuum 32, no. 6, 770-781.

Ojala, Markus \& Timo Harjuniemi. 2016. "Mediating the German Ideology: Ordoliberal Framing in European Press Coverage of the Eurozone Crisis." Journal of Contemporary European Studies 24, no. 3, 414-430.

Orléan, Andre. 2014. The Empire of Value. A New Foundation for Economics. Boston: MIT Press.

Pistor, Katharina. 2013. "A legal theory of finance." Journal of Comparative Economics 41, no. 2, 315-330.

Preiss, Joshua. 2018. "Did we trade freedom for credit? Finance, domination, and the political economy of freedom". European Journal of Political Theory. https://doi.org/10.1177/1474885118806693.

Prinz, Janosch and Enzo Rossi. 2017. "Political Realism as Ideology Critique." Critical Review of International Social and Political Philosophy, 20, 334-348.

Reinhart, Carmen M., and Rogoff, Kenneth S. 2010. "Growth in a Time of 
Debt." American Economic Review 100, no.2, 573-78.

Romei, Valentina. 2018. "In charts: Greece's economy is rebounding - but there is far to go". Financial Times, 18 August 2018, retrieved at https://www.ft.com/content/3067bf9c-8a88-11e8-bf9e-8771d5404543.

Roos, Jerome. 2019. Why not default. The political economy of sovereign debt. Oxford and Princeton: Princeton University Press.

Rossi, Enzo \& Carlo Argenton. 2020. „Property, Legitimacy, Ideology: A Reality Check", The Journal of Politics, forthcoming. URL: https://www.academia.edu/20364200/Property_Legitimacy_Ideology_A _Reality_Check

Rossi, Enzo. 2019. 'Being Realistic and Demanding the Impossible', Constellations, 26, pp.638-652.

Roufos, Pavlos. 2018. A Happy Future is a Thing of the Past: The Greek Crisis and other Disasters. Chicago: University of Chicago Press.

Sanchez-Cuenca, Ignacio. 2017. "From a Deficit of Democracy to a Technocratic Order: The Postcrisis Debate on Europe." Annual Reviews of Political Science 20, 351-69.

Schäuble, Wolfgang. 2012. Interview with Harald Schumann (2012) 'Talking to Wolfgang Schäuble, Harald Schumann on the trail - the complete interview', available at https://www.youtube.com/watch?v=XXdmJ5cVDXU (part of the film production "Staatsgeheimnis Bankenrettung"

Schelkle, Waltraud The political economy of monetary solidarity: revisiting the Euro experiment. Wirtschaft und Gesellschaft, 44 (3). pp. 335-367.

Sgambati, Stefano. 2019. "The art of leverage: a study of bank power, moneymaking and debt finance, Review of International Political Economy 26 (2), 287-312.

Simou, Effie and Eleni Koutsogeorgou. 2014. "Effects of the economic crisis on health and healthcare in Greece in the literature from 2009 to 2013: A systematic review." Health Policy 115 (2-3), 111-119.

Sleat, Matt. 2014. "Legitimacy in Realist Thought: Between Moralism and Realpolitik." Political Theory 42(3), 314-337.

Sleat, Matt. 2016. "What is a political value? Political Philosophy and Fidelity to Reality" Social Philosophy and Policy 33(1-2), 252-272.

Stasavage, David. 2003. Public Debt and the Birth of the Democratic State. France and Great Britain, 1688-1789. Cambridge: Cambridge University Press.

Tooze, Adam. 2018. Crashed. How a decode of financial crises changed the world. London and New York: Penguin Random House.

Vaara, Eero. 2014. "Struggles over legitimacy in the Eurozone crisis: Discursive legitimation strategies and their ideological underpinnings." Discourse \& Society 25, no. 4, 500-518.

Varoufakis, Yanis. 2020. "Solidarity with the Germans", Project Syndicate, 3 August 2020, retrieved at https://www.projectsyndicate.org/commentary/next-generation-eu-recipe-for-divisivenessparalysis-by-yanis-varoufakis-2020- 
08?utm_source=facebook\&utm_medium=organicsocial\&utm_campaign=page-posts-august20\&utm_posttype $=$ link\&utm_format $=16: 9 \& u t m \_c r e a t i v e=l i n k$-image\&utm_postdate $=2020-08-03$

Verde, Antimo. 2011. "The Greek Debt Crisis. Causes, Policy Responses, and Consequences." In Europe and the Financial Crisis edited by P. Della Post et al., 143-164. Basingstoke: Palgrave Macmillan.

Verovsek Peter J. 2017. "The Immanent Potential of Economic and Monetary Integration: A Critical Reading of the Eurozone Crisis." Perspectives on Politics 15, no. 2, 397-410.

Wiedenbrüg, Anahí. 2017. "What Creditors Owe." Constellations 25, no.1, 101-116.

Wiedenbrüg, Anahí. 2018. "What Citizens Owe: Two Grounds for Challenging Debt Repayment." Journal of Political Philosophy 26, no. 3, 368-387.

Williams, Bernard. 2005. In the Beginning was the Deed. Moralism and Realism in Political Argument, edited by Geoffrey Hawthorn. Princeton and Oxford: Princeton University Press.

Winters, Jeffrey. 2011. Oligarchy. Cambridge: Cambridge University Press.

Wollner, Gabriel. 2018. "Morally Bankrupt: International Financial Governance and the Ethics of Sovereign Default". Journal of Political Philosophy 26, no. 3, 344-367.

Wren-Lewis, Simon. 2015. "The Austerity Con." London Review of Books, 37, no. 4, available at https://www.Irb.co.uk/v37/n04/simon-wren-lewis/theausterity-con

Young, Iris Marion. 2001. "Activist Challenges to Deliberative Democracy." Political Theory 29, no. 5, 670-690. 